\title{
Vivências da espiritualidade em mulheres brasileiras e britânicas praticantes de Tai Chi Chuan
}

\author{
Nicole Bacellar Zaneti \\ Marta Helena de Freitas \\ Jeremy Carrette
}

\section{RESUMO}

Apresenta-se pesquisa desenvolvida com mulheres brasileiras e britânicas praticantes de Tai Chi Chuan (TCC), cujo objetivo foi identificar suas vivências de espiritualidade, pautando-se nas contribuições de Husserl e Merleau-Ponty para compreender as relações entre espiritualidade e corporeidade. Foram entrevistadas, em profundidade, doze mulheres (seis brasileiras e seis britânicas), sendo que este recorte foi focado sobre os temas eixos: "vivência e concepção do TCC" e "vivência e concepção de espiritualidade". As entrevistas - gravadas, transcritas e revisadas - foram analisadas segundo metodologia fenomenológica de Giorgi. Os resultados mostram que as praticantes de TCC o valorizam profundamente em suas vidas e o associam a uma série de benefícios físicos, mentais e existenciais. Suas concepções e vivências da espiritualidade, ainda que mescladas numa teodiceia ocidental, tendem a ser bastante influenciadas e, eventualmente, substituídas por paradigmas orientais, integrando-se à vivência corporal, em consonância com o que Campbel chamou de "orientalização do Ocidente".

Palavras-chave: espiritualidade; religiosidade; Tai Chi Chuan; mulheres; psicologia da religião.

\section{ABSTRACT}

\section{Spiritual experiences in brazilian and british Tai Chi female practitioners}

This paper presents research with Brazilian and British female practitioners of Tai Chi Chuan (TCC). Its objective was to identify their experiences of spirituality, based on the contributions of Husserl and Merleau-Ponty to understand the relationship between spirituality and corporeity. Twelve women (six Brazilians and six Britons) were interviewed in depth, focusing on the themes "experience and conception of TCC" and "experience and conception of spirituality". The recorded, transcribed and revised interviews were analyzed according to Giorgi's phenomenological methodology. The results show that practitioners deeply value TCC's role in their lives and associate it with a range of physical, mental and existential benefits. Their conceptions and experiences of spirituality, although mixed in Western theodicy, tend to be heavily influenced and eventually replaced by Eastern paradigms, integrating bodily experience, according to what Campbell called the Orientalization of the West.

Keywords: spirituality; religiosity; Tai Chi Chuan; women; psychology of religion.

Como parte daquilo que Campbel (1997) chamou de "orientalização do Ocidente", tem-se observado, já há algumas décadas, relevante expansão das religiosidades orientais nos países ocidentais. Embora esse processo seja bem mais complexo e não deva ser reduzido à mera introdução e difusão no Ocidente de práticas e produtos originários do Ocidente, é digna de nota a tendência à substituição de uma teodiceia tradicional cristã por outra de cunho oriental, por meio da assimilação de filosofias, atividades e crenças, dentre elas o Taoísmo, cujas proposições estão também na base do Tai Chi Chuan (TCC), atividade física que envolve

\section{Sobre os Autores}

N. B. Z.

orcid.org/0000-0002-8093-7164

Universidade Católica de

Brasília e IESGO - Brasília - DF

nbzaneti@gmail.com

M. H. F.

orcid.org0000-0003-1552-6016

Universidade Católica de

Brasília - Brasília - DF

mhelenadefreitas@gmail.com

J. C.

orcid.org/0000-0001-5708-6034

University of Kent - CanterburyInglaterra

J.R.Carrette@kent.ac.uk

\section{Direitos Autorais}

Este é um artigo de acesso aberto e pode ser reproduzido livremente, distribuído,

transmitido ou modificado, por qualquer pessoa desde que usado sem fins comerciais. 0 trabalho é disponibilizado sob a licença Creative Commons CCBY-NC.

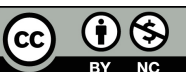


É verdade que os contextos de assimilação dessa prática se deram no âmbito de um crescente interesse ocidental pelo esoterismo, pela leitura ocidental das tradições orientais como na teosofia, pela atitude chamada New Age, sincrética e não dogmática -, pela sensibilidade às questões ecológicas, dentre várias outras formas de expressão que buscaram ampliar o espaço ecumênico multicultural e multirreligioso. É também digno de nota o quanto o TCC ganha visibilidade no contexto das novas racionalidades médicas e práticas de saúde nos países ocidentais, passando a compor novos paradigmas terapêuticos, conforme ilustra sua adoção nas terapias complementares e alternativas em contexto hospitalar e da saúde mental (Mateu, 2015; Nascimento, Barros, Nogueira \& Luz, 2013; Nogueira \& Camargo, 2007; Saizar, Sarudiansky \& Korman, 2013; Tesser, 2009; Tesser \& Barros, 2008) em países europeus e americanos, incluindo-se Reino Unido e Brasil.

Nas primeiras décadas do século XXI, multiplicam-se pesquisas constatando efeitos positivos da prática do TCC sobre o bem-estar e sobre a saúde física e mental da mulher, em especial depois da menopausa e/ou na velhice. Dentre as mais recentes, estão os trabalhos de Montanelli (2018), investigando efeitos psicológicos e corporais dessa prática sobre a qualidade de vida em idosas; Guimarães, Lima e Cardoso (2017), avaliando efeitos da prática do TCC na autoestima e autoimagem de idosos da área urbana, sendo que quase $70 \%$ da amostra foi composta por mulheres; Chao, Costa, Elsangedy, Savir, Alves, e Okano (2012), analisando percepção subjetiva do esforço, resposta afetiva e pressão arterial pós-exercício em sessão aguda de TCC com mulheres entre 47 e 79 anos de idade; Chyu et al. (2010) e Silva (2012), respectivamente, identificando efeitos da prática do TCC sobre o equilíbrio em mulheres na pós-menopausa com osteopenia e em idosas com baixa massa óssea.

Considerando-se a hipótese de que a prática do TCC se insere no contexto de uma possível substituição de teodiceia ocidental por uma de cunho oriental, o trabalho aqui apresentado investigou o modo como mulheres britânicas e brasileiras, praticantes dessa atividade, concebem e experimentam a espiritualidade. 0 estudo se fundamenta nas contribuições de Husserl (2008/1936) e Merleau-Ponty (1973/1951, 1999) para a compreensão das noções de espiritualidade e corporeidade, respectivamente.

\section{ESPIRITUALIDADE, RELIGIOSIDADE E RELIGIÃO}

No contexto ocidental, mais especificamente no campo da Psicologia da Religião, o emprego dos termos espiritualidade e religião tendeu a ocorrer de forma conjugada, durante décadas consecutivas, até meados do século passado. Era, pois, comum a oscilação no emprego dos dois conceitos em títulos de obras de autores pioneiros (Freitas, 2016, 2017, 2019). Nesse período, a religião poderia ser compreendida, então, como uma experiência humana que, necessariamente, envolve adesão espiritual pessoal. Segundo Aletti (2012), a dicotomia entre os dois termos surgiu na segunda metade do século passado, mobilizada pela crítica ao termo religião, que passou a ser associado a dogma, doutrinação, instituição e ortodoxia, enquanto o termo espiritualidade ficou reservado à experiência interior pessoal, ligada às demandas de significado existencial, mas de forma livre e criativa, sem vinculações a elementos moralistas, padronizados e valorativos. Nessa perspectiva, dicotômica, religião passou a ser facilmente associada a sintoma de alienação ou repressão, enquanto que espiritualidade remeteria à vida saudável. Não seria incorreto interpretar essa tendência à maior valorização da noção de espiritualidade, também como reflexo daquilo a que Campbel (1997) chamou de orientalização do Ocidente, embora paradoxalmente a polarização em si, entre religião e espiritualidade, reflita um discurso dicotômico tipicamente ocidental.

Entretanto, mesmo no contexto ocidental, o reducionismo dessa polarização entre religião e espiritualidade tem sido criticada por vários autores (Aletti, 2012; Carrette, 2007; Carrette \& King, 2005; Koenig, 2006; Paiva, 2004) por carregar o risco de se perder numa fragmentação analítica, científica, tecnológica e individualizada, levando à alienação da própria experiência humana fundamental em causa. Nos últimos anos, essa dicotomia tem ganhado cada vez mais espaço na linguagem comum e dos profissionais de saúde em geral. Nesta pesquisa, evitou-se incorrer nessa polarização, embora atentando-se à sua possível presença no discurso de mulheres britânicas e brasileiras entrevistadas. Nesse sentido, a adoção da postura fenomenológica favoreceu compreender a dinâmica de inter-relações entre os dois termos, como também as vivências relatadas pelas participantes da pesquisa.

Em "A crise da humanidade europeia e a filosofia", Husserl (2008/1936), realizando a crítica aos rumos tomados pela sociedade ocidental, compreende a espiritualidade como manifestação humana, argumentando que seu estudo deve ser voltado exclusivamente "aos homens como pessoas e às suas vidas e realizações pessoais, bem como, correlativamente, às figuras dessas realizações" (p.12). Isso implica considerar que não existiria uma espiritualidade dissociada das figuras de suas realizações, assim como não existe intencionalidade sem objeto. Desse modo, as figuras às quais a espiritualidade é dirigida podem ser ligadas ao sagrado, à religião, à filosofia, à cultura, à natureza, dentre outras tantas possibilidades. Ocorre que, para um grande 


\section{W INERACÄOEM ET PSICOLOGIA}

contingente da população ocidental, em especial a brasileira, essas figuras de realizações são moldadas pela adesão religiosa, como mostrou pesquisa nacional conduzida por Moreira-Almeida, Pinsky, Zaleski e Laranjeira (2010). Sendo assim, mesmo que se tome a religião como organização institucional, que inclui crenças, valores, mitos e ritos relacionados à questão do Último, integrados em um corpo social hierárquico - e ao qual algumas pessoas aderem, ainda assim, ela se constitui, para os religiosos, a figura pela qual se busca a conectividade e formulação de sentido (característica da espiritualidade). Desse modo, se a espiritualidade é situada no polo caracterizado pela busca e pergunta fundamental de sentido da existência, a religião se situará no polo da possível resposta, compartilhada coletivamente, seja no âmbito de um grupo religioso, de uma igreja específica ou de uma teodiceia mais abrangente, dada pelo ethos culturalmente assimilado.

Em consonância com esse modo de compreender a experiência humana, de inspiração husserliana, o termo religiosidade, por sua vez, pode ser reservado para se referir à experiência pessoal de cada indivíduo. Ou seja, ao modo como cada pessoa organiza sua resposta à demanda de sentido (espiritualidade) com base em suas próprias crenças em seres ou dimensões que a transcendem. Assim, uma pessoa pode responder a grande pergunta de sentido existencial atribuindo significado às suas experiências a partir de uma concepção religiosa, mas sem que esta corresponda a uma organização institucional específica ou implique adesão a um grupo ou doutrina claramente formulada. Mesmo assim, há que se lembrar outra assertiva husserliana que admite íntima conexão e inter-relação entre experiência humana e contexto de vida: "vida pessoal significa viver num horizonte comunal, como eu comunal e nós" (Husserl, 2008/1936, p.12). Ou seja, as experiências de espiritualidade, por mais pessoais que sejam, assim como as de religiosidade e as de religião, sempre apresentam relações com o contexto existencial, social e cultural em que a pessoa se insere e para o qual dirige seus movimentos de realização e autorrealização.

Em consonância com esse modo de compreensão, a Figura 1, reproduzida de Freitas e Vilela (2017), busca apresentar as relações entre os três termos - espiritualidade, religiosidade e religião - ilustrando graficamente e simultaneamente suas especificidades e suas interconexões.

\section{ESPIRITUALIDADE E CORPOREIDADE}

A concepção husserliana, em especial na sua última fase, critica a separação entre subjetividade e mundo objetivo, típica do pensamento ocidental, adotando a noção de Lebenswelt (ou mundo da vida). Disso decorre que a experiência vivida como espiritual não estaria cortada de suas raízes corporais e sensíveis. Merleau-Ponty (1999/1945) radicalizará essa reflexão ao afirmar, por exemplo, que o pensamento objetivo não poderá "encontrar uma só função corporal que seja rigorosamente independente das estruturas da existência, e reciprocamente um só ato "espiritual" que não repouse em uma infraestrutura corporal" (p. 577). Do ponto de vista fenomenológico, então, a espiritualidade, assim como toda experiência humana, encontra na corporeidade a sua ancoragem fundamental, ao mesmo tempo que dela transcende. O corpo vivido apresenta-se como instância pré-reflexiva, como experiência originária, uma espécie de pré-predicação para a demanda e o encontro de sentidos, que caracterizam a experiência espiritual.

Compreendida dessa maneira, então, a vivência da espiritualidade não se fecha nela mesma e, portanto, não terá necessariamente caráter regulador das ações humanas, como teria a religião, ao situar-se no âmbito das respostas

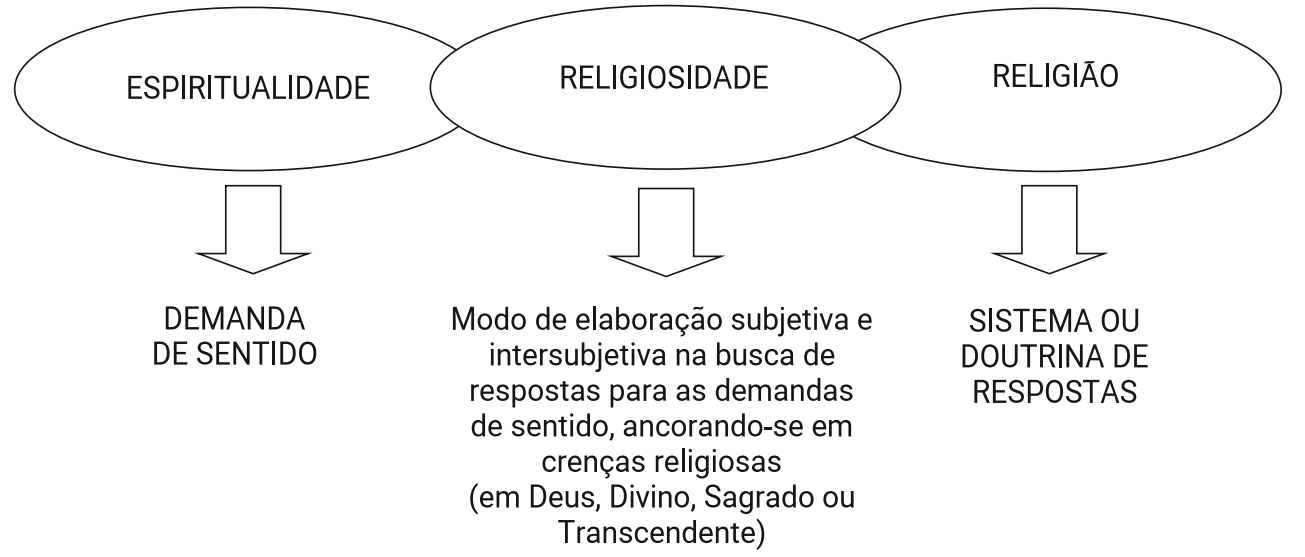

Figura 1: Concepção de espiritualidade. Fonte: De "Leitura fenomenológica da religiosidade: Implicações para o

psicodiagnóstico e para a práxis clínica psicológica" de M. H. Freitas e P. R. Vilela, 2017, Rev. Abordagem Gestalt, 23(1), p. 97.

Disponível em: http://pepsic.bvsalud.org/scielo.php?script=sci_arttext\&pid=S1809-68672017000100011 
compartilhadas e, portanto, já objetivadas. A noção de corporeidade, compreendida a partir da complementaridade entre as noções de intencionalidade e sentido, oferece então a ancoragem para uma postura de integração entre experiência espiritual e mundo da vida, tendo como princípio a ideia de continuidade pessoa-mundo, consciência-objeto, sendo a pessoa uma totalidade. Assim, para Merleau-Ponty (1999/1945), o corpo é um modo do espaço objetivo, sempre em direção ao mundo. E, nesse sentido, "a união da alma e do corpo não é lacrada por um decreto arbitrário entre dois termos exteriores, um objeto, outro sujeito. Ela se completa em cada momento no movimento da existência" (p.101).

Essa perspectiva fenomenológica, embora concebida no contexto ocidental, mostra-se útil para compreender os princípios que estão na base da prática do TCC, os quais não correspondem às noções modernas de "realidade". Ao invés disso, essa prática reflete um estilo chinês de espiritualidade que tem fé na autopercepção psicossomática e, ao mesmo tempo, incorpora a imortalidade. Nesse sentido, ela está em sintonia com a visão merleaupontiana de que referir-se a corpo não significa necessariamente voltar-se apenas à sua dimensão material (Körper), mas ao corpo animado (Leib), dotado de "anima", "espírito". Desse modo, o corpo de que se tem consciência sintetiza a ambiguidade (imanência/ transcendência) do ser no mundo, sendo a imanência e a transcendência dois elementos estruturais de qualquer ato perceptivo. Ou seja, a relação entre corporeidade e funções psíquicas superiores, incluindo-se a espiritualidade, carrega "o mistério de um conjunto que, sem abandonar sua ecceidade e sua particularidade, emite, para além de si mesmo, significações capazes de fornecer sua armação a toda uma série de pensamentos e de experiências" (MerleauPonty, 1999/1945, p. 178). Essa potencialidade constitui-se no fundamento da liberdade existencial, em que a existência pessoal se assume como única, mas, ao mesmo tempo, dotada de extensão para além de si mesmo.

\section{SOBRE O TAI CHI CHUAN}

Diz-se que o TCC, ou Taijiquan, tem sua origem nas artes marciais na China, fazendo referência aos ideogramas chineses que significam: Tai - supremo, grandioso; Chi - vigamestra, eixo; Chuan - boxe, punho, golpe. A expressão Taijiquan significa, literalmente, "boxe da Suprema Cumeeira" (Despeux, 1981). Porém, as especulações sobre sua origem não constituem um consenso, sendo um dos mais polêmicos assuntos na história da China (Wile, 2008). Uma das versões mais conhecidas e aceitas remete a cerca de $1200 \mathrm{dC}$, quando um monge da dinastia Sung, no templo Shaolin, criou o Estilo Wudang de TCC depois de ter observado a luta entre uma garça e uma serpente (Silva, 2010). Ele teria percebido que a suavidade e a flexibilidade são capazes de vencer a rigidez e a dureza, e que a harmonia brota do equilíbrio entre Yin (flexível) e Yang (forte), sendo fundamental para a saúde do corpo e da mente. Desse modo, incluiu na prática do TCC a meditação, o controle da respiração e os movimentos naturais do corpo. Já para Chang (1979, p. 137), o TCC teria começado com uma "dança graciosa" inventada à época do imperador Fu-Hsi, com o intuito de promover alegria e prevenção de doenças. Depois, com a Dinastia Han, a prática recebeu contribuições do médico Hua T'o, observador da natureza e da vida selvagem, que sentiu que os animais poderiam ensinar muito aos homens sobre força e manutenção das condições físicas.

O TCC pode ser considerado uma filosofia ou uma linhagem, algo genérico ou uma marca. Os estilos que reivindicam um conteúdo filosófico taoísta têm a pretensão de serem portadores de uma transmissão original de um famoso imortal. Entretanto, conforme aponta Wile (2008), os escritos clássicos sobre Tai Chi não citam diretamente Lao Tse, autor do Tao Te Ching, obra basilar da filosofia taoísta, mas citam o I Ching, fonte da qual o Taoísmo bebeu. 0 autor afırma que a conexão taoísta-taiji na China foi cuidadosamente construída, e contestada ferozmente, mas foi apresentada ao Ocidente como um fato consumado.

Atualmente, o TCC é praticado pela manhã por pessoas de todas as idades, nos parques das grandes cidades da China e, também, em países ocidentais. No Reino Unido, pesquisas apontam aumento da popularidade do seu uso para combater stress problemas físicos e mentais, especialmente entre idosos, sendo que o Serviço Nacional de Saúde (NHS) assume que a prática do TCC, exercida de modo adequado, pode prevenir quedas, aumentar o bem-estar, promover flexibilidade e equilíbrio (Lindquist, Tracy \& Snyder, 2018). No Brasil, ele tem sido empregado nos serviços do Sistema Único de Saúde (SUS) como parte da Política Nacional de Práticas Integrativas e Complementares (PNPIC). O campo das práticas integrativas e complementares contempla sistemas médicos complexos e recursos terapêuticos denominados pela Organização Mundial da Saúde (OMS) como Medicina Tradicional e Complementar/ Alternativa (MT/MCA), incluindo práticas corporais típicas da Medicina Tradicional Chinesa, dentre elas o TCC, relacionadas à prevenção de doenças, promoção e recuperação da saúde (Brasil, 2006).

\section{MÉTODO}

Participaram da pesquisa 12 mulheres, com idade entre 50 a 70 anos de idade, sendo seis brasileiras, residentes em Brasília, e seis britânicas, residentes na Inglaterra, todas elas praticantes e professoras de TCC há pelo menos dois anos. Elas foram contatadas inicialmente, por telefone, por uma 


\section{-4* INTERACÃO EM LF PSICOLOGIA}

das pesquisadoras, sendo informadas sobre a pesquisa e solicitadas a colaborarem como participantes, cedendo uma entrevista que contemplaria as temáticas da sexualidade e espiritualidade (ambas abordadas numa pesquisa mais abrangente e da qual o trabalho aqui apresentado é um recorte focado apenas no segundo tema).

Após concordância em participar da pesquisa $e$ assinatura do Termo de Consentimento Livre e Esclarecido (TCLE), cada participante foi entrevistada individualmente, em geral no seu próprio local de trabalho. A entrevista seguiu roteiro semiestruturado com os seguintes temas eixos: (a) Vivência no TCC; (b) Vivência e concepção de espiritualidade; (c) Vivência e concepção de sexualidade; (d) Relações que estabelece (ou não) entre a vivência da espiritualidade e a da sexualidade; (e) Recomendações às mulheres que experimentam conflitos entre vivência da sexualidade e da espiritualidade. Para o recorte contemplado neste artigo, são tomados como focos de análise apenas os tópicos (a) e (b).

Condizente com uma postura fenomenológica, os diálogos entre entrevistadora e entrevistadas não ficaram restritos apenas ao roteiro e ocorreram conforme fluxo espontâneo de expressão de cada entrevistada. Ou seja, as questões relacionadas no roteiro semiestruturado tiveram apenas a função de apontar eixos norteadores e possíveis questões disparadoras durante a entrevista, não se constituindo em estrutura rígida seguida pelo entrevistador. Tal flexibilidade e espontaneidade visou garantir a vantagem interativa da entrevista, promovendo relatos mais refinados, detalhados, autênticos e profundos, em que o vivido pode ser surpreendido em ato (Amatuzzi, 2001). Por outro lado, o roteiro se mostra útil, na medida em que o interesse da entrevistadora não se restringia apenas à vivência particular de uma determinada pessoa, em um certo ambiente, pois a pesquisa fenomenológica não está à procura apenas da subjetividade (Gomes, 1997). Seu interesse é saber como diferentes pessoas experienciam uma dada condição comum a elas, neste caso, a prática do TCC e a vivência da espiritualidade.

Todas as entrevistas foram gravadas, com o devido consentimento das entrevistadas, e posteriormente transcritas e revisadas. Sobre as transcrições, realizou-se leitura e análise fenomenológica, em moldes descritos por Giorgi $(2009,2012)$, fiel aos seguintes passos:

1) Apreensão do sentido do todo: leituras sucessivas do material, visando apreender, em conjunto e de modo integrado, os objetos intencionais na descrição da experiência vivida e compartilhada por cada participante.

2) Discriminação das unidades de significado: releitura detalhada de cada entrevista, acompanhada da marcação de cada trecho em que se identifica uma nuance de significação específica. A cada mudança de significado, inicia-se nova marcação, de modo que, ao final, a entrevista fica distribuída numa série de recortes que se constituem em diferentes unidades de significado, identificadas a partir de atividade experiencial e intuitiva, e não apenas intelectual.

3) Tradução em expressões psicológicas fenomenologicamente sensíveis: transformação das expressões naturais empregadas pelos entrevistados em linguagem psicológica, buscando alcançar certo grau de invariância dos significados, favorecendo a integração dos dados de vários participantes em uma mesma estrutura, mas de modo a não perder a perspectiva intuitiva, descritiva, fenomenológica e compreensiva.

4) Identificação das unidades de sentido (US): aqui as expressões psicologicamente mais sensíveis são revisadas e nomeadas, com ajuda da livre variação imaginativa, empregando-se expressões mais sintéticas e expressivas da estrutura essencial da experiência descrita (Giorgi, 2012).

5) Integração das US, buscando chegar à estrutura geral do vivido, em articulação com o sentido apreendido do todo. Favorecendo essa meta, as US foram nucleadas em torno de eixos integradores, aqui nomeados como núcleos de sentido (NS).

No decorrer das etapas acima descritas, organizou-se o material descritivo em consonância com cada um dos dois grandes eixos temáticos focados neste trabalho: (a) Vivência e concepção do TCC, e (b) Vivência e concepção da espiritualidade.

\section{RESULTADOS}

\section{VIVÊNCIA E CONCEPÇÃO DO TAI CHI CHUAN}

Conforme ilustrado na Figura 2, das vivências e concepções sobre o TCC, compartilhadas pelas entrevistadas, emergiram três grandes NS: um primeiro, em que elas relatam uma série de benefícios físicos e emocionais que passaram a experimentar desde que passaram a exercer essa prática (NS1 - Vivência de benefícios com o TCC); um segundo, em que expressam os sentidos que o TCC passou a adquirir em suas vidas, ao longo de sua prática continuada (NS2 - Sentidos da vivência no TCC); e um terceiro, em que compartilham o modo como hoje definem essa prática (NS3 - Definição de TCC). Como se vê na Figura 2, em que cada desses três núcleos de sentidos se desdobram as US.

Do primeiro núcleo, benefícios do TCC (NS1), desdobramse duas US. Uma primeira, referente aos benefícios físicos (US1), em que mencionaram a melhora de doenças físicas 


\section{4.' INTERAÇ̃̃O EM ET PSICOLOGIA}

diversas, como artrose, fibromialgia, dores crônicas em partes específicas do corpo, como ombro, joelho, além da aquisição do fortalecimento da musculatura, melhora na postura e na qualidade do sono. Essa US foi identificada no relato de experiências de todas as entrevistadas, brasileiras e britânicas. A segunda US, referente aos benefícios emocionais (US2), emergiu na fala de três brasileiras e quatro britânicas, fazendo referências ao quanto a prática continuada do TCC veio acompanhada de mais tranquilidade, serenidade, equilíbrio, segurança e harmonização nas vivências das próprias emoções, reduzindo sintomas de depressão e ansiedade, e favorecendo seus relacionamentos pessoais. Seguem vinhetas ilustrativas.

[...] o Tai Chi me deu essa visão, né, de que você pode trabalhar tua energia se situando de uma maneira correta, equilibrada no ambiente em que você está, dentro e fora, é muito fácil, muito simples, depois que você consegue incorporar isso (...) e você se harmonizar e... enfim, não deixar que as influências externas negativas que podem te fazer mal, se... tomem conta do teu equilíbrio então uma forma de defesa, também uma forma de contribuir para harmonia do ambiente, né, você poder estar se relacionando com as pessoas de maneira mais saudável. (Marina, brasileira) ${ }^{\star \star}$

Tem sido fantástico para mim, eu sofria com ansiedade, depressão e coisas dessa natureza, e acho que o tai chi realmente fez uma grande diferença, de modo que, hoje em dia, eu fico deprimida, mas não fico perdida por três meses, sabe? (Bárbara, britânica).**

Do segundo núcleo, sentidos da vivência do TCC (NS2), desdobram-se três US. Uma primeira em que são expressos os significados da prática do TCC logo que as entrevistadas

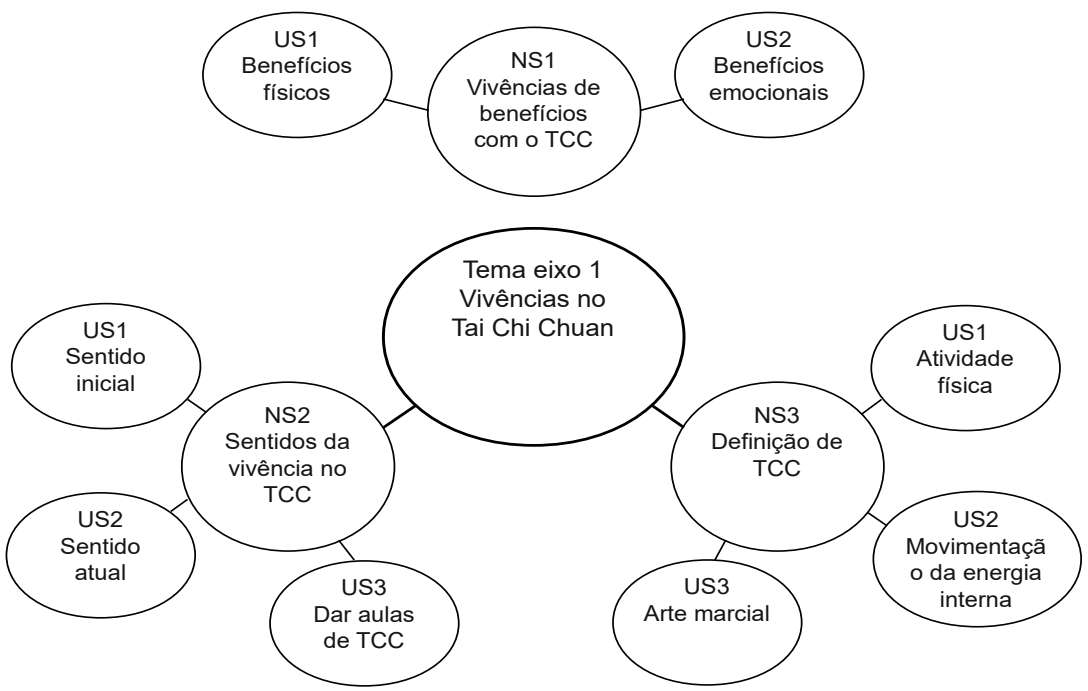

Figura 2: Vivências e concepcões do TCC. Fonte: De "Sexualidade e espiritualidade femininas: um estudo com mulheres praticantes de Tai Chi Chuan", de N. B. Zaneti, 2017, p. 66

iniciaram a praticá-lo (US1 - Sentido inicial). Aqui se destacaram referências à busca de autocuidado, autoconhecimento, relaxamento, família, sociabilidade, prática de atividade física, atividade artístico-filosófica, equilíbrio, dentre outros. Numa segunda unidade, são contemplados os sentidos atuais da prática (US2 - Sentido atual), emergindo aí uma série de metáforas significativas para caracterizar o significado do TCC na vida das entrevistadas, e.g., "alimento espiritual", "essência de vida", "filosofia existencial", "momento para si mesma", "estrutura e disciplina na vida". Ainda nessa US, foram comuns adjetivos caracterizando o sentido da prática, e.g., "empolgante", "emocionante", "motivador de orgulho", ou o emprego de substantivos bastante expressivos, como "orgulho", "responsabilidade", "vida, mais que propriamente um trabalho". Numa terceira unidade, emerge o sentido do TCC como uma prática de ensino (US3 - Dar aulas de TCC), recorrentemente apontada pelas entrevistadas como forma de doação, de compartilhar com outras pessoas o que assimilaram ao longo de suas próprias experiências com a prática do TCC, de ajudar o mundo a se tornar um lugar melhor. $\mathrm{O}$ ensino do TCC foi também apontado como uma nova área de aspiração que emergiu em idade já mais avançada a partir do amor pela prática, desenvolvido ao longo dos anos, e de novo emergem as metáforas, os adjetivos e os substantivos expressivos para se referirem agora à própria prática de ensino do TCC: "é a minha vida", "estrutura e disciplina de vida", "empolgante", "nutritivo", "orgulho" e "responsabilidade". Algumas vinhetas para ilustrar: 


\section{W'INTERACÃO EM इTSPSICOLOGIA}

[...] ... muitos dos meus clientes vêm até mim e dizem o quão melhor eles se sentem por praticar o tai chi, sabe? Eu realmente gosto disso porque, tudo bem, não fui eu quem fez isso, foi o tai chi que fez, mas eu fui o canal para isso, e também tornei possível que essas pessoas se sentissem melhores. [...] É apenas uma sensação boa. Porque acredito que estamos aqui na Terra para tentar fazer do mundo um lugar melhor. Então, pra mim, ensinar o tai chi é a minha maneira de ajudar o mundo a ser um pouco melhor, mesmo que seja de uma maneira minusculamente pequena. (Alicia, britânica) **

[...] ... eu partilho, partilho, compartilho com outras pessoas aquilo que eu aprendi no tai chi, [...] Eu não gosto de dizer que eu dou aula porque, enfim, embora eu tenha sido certificada para tal, eu não acho que se dê aula de Tai Chi, eu acho que a gente compartilha o Tai Chi. (Vera, brasileira)**

Eu gradualmente comecei a dar mais aulas, então, é como um emprego em tempo integral agora, no entanto eu percebi que não é um trabalho, pois isso é o que eu amo fazer. Na verdade, é minha vida agora, não é trabalho, não é meu hobby, é minha vida. Tornou-se minha vida. [...] (Linda, britânica)**

No terceiro núcleo, geralmente deflagrado pela pergunta da entrevistadora "O que é TCC para você?", emergem as definições do TCC (NS3), que se distribuíram em três US. Uma primeira, cujo escopo girou em torno do TCC como uma atividade física (US1), mesmo que englobando o Chi Kung, uma prática chinesa que trabalha com alongamentos, ou trabalhando também com aspectos internos da pessoa. Uma segunda unidade emerge com a definição do TCC como movimentação da energia interna da pessoa (US2), a qual promove a cura, por caracterizar um movimento que se dá de dentro para fora e não o oposto. Uma terceira US referencia o TCC como arte marcial (US3), que trabalha com movimento voltado para o exterior da pessoa, ataque e defesa.

\section{VIVÊNCIA E CONCEPÇÃO DA ESPIRITUALIDADE}

A nucleação das expressões acerca das vivências e concepções de espiritualidade resultou em quatro grandes NS: Concepção de espiritualidade (NS1); vivências da espiritualidade enquanto mulher (NS2); vivências da própria da religião (NS3), e influências do TCC nas suas vivências da espiritualidade (NS4).

Em torno do primeiro NS, as concepções de espiritualidade (NS1) que emergiram da leitura fenomenológica das entrevistas compuseram seis US, conforme ilustra a Figura 3. A primeira delas emergiu nas falas de quatro entrevistadas, três brasileiras e uma britânica, remetendo a noção de espiritualidade a um ser específico e superior, Deus ou o Tao (US1), caracterizado como uma inteligência suprema que está simultaneamente na terra, no céu e no homem. A segunda US emergiu nas expressões de três entrevistadas, duas brasileiras e uma britânica, remetendo a espiritualidade às noções de energia, espírito, força e inteligência (US2). Aqui cabe destacar frequentes comparações espontâneas entre espiritualidade e religião, das quais emergiu o NS 3, conforme será descrito mais adiante. Nessas comparações, em especial por parte das britânicas, foram frequentes críticas à religião, por ser dogmática, e à cultura ocidental, por ser materialista.

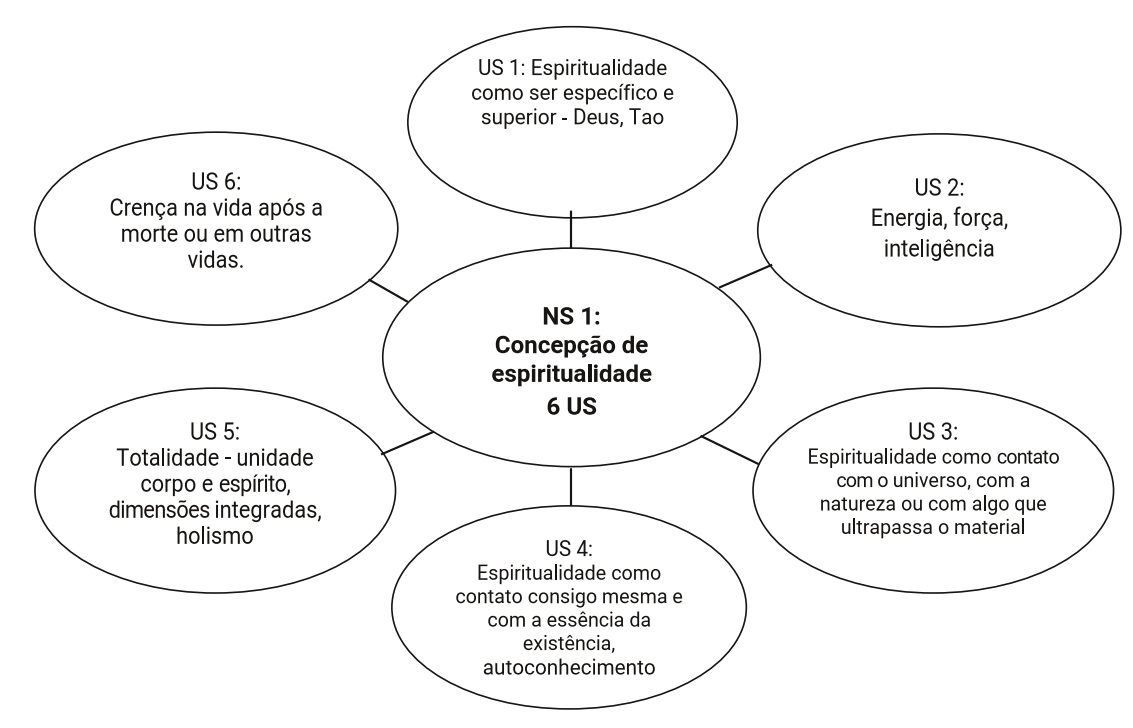

Figura 3: Concepção de espiritualidade. Fonte: De "Sexualidade e espiritualidade femininas: um estudo com mulheres praticantes de Tai Chi Chuan", de N. B. Zaneti, 2017, p. 82. 


\section{W'INTERACÃO EM ET PSICOLOGIA}

Uma terceira modalidade de sentido, nas concepções de espiritualidade, emerge ao caracterizar a espiritualidade como contato com o universo, com a natureza ou algo além do âmbito material ou concretamente visível (US3). Cinco entrevistadas, quatro britânicas e apenas uma brasileira, expressam-se nessa direção. De novo aqui se registrou nuances expressivas mais características das mulheres britânicas, ao evitarem a referência explícita à concepção de Deus, e das mulheres brasileiras, ao verem o universo como presença d'Ele, conforme ilustram as vinhetas.

[...]... a respeito da religião. Eu acredito que é uma forma de espiritualidade, mas pra mim a espiritualidade é mais do que isso. Não é necessariamente uma divindade em que todos nós acreditamos, mas acho que a espiritualidade tem a ver com o universo, há algo mais lá, tem algo lá. [...]... eu não sei o que está além, mas há algo de especial quando você se conecta com o universo. Eu experimentei muitas vezes... (Linda, britânica)

A espiritualidade, eu penso assim, quando estou no meio da natureza, esse contato, essa contemplação, esse ouvir, isso é...[...]... eu entendo que nesse canto tem a mão de Deus, tudo, nesse grãozinho de terra, tem essa essência, então eu acho que é isso... (Aparecida, brasileira)

Numa quarta US, a espiritualidade é remetida ao contato consigo mesma, com a essência da existência evolutiva e/ou com o autoconhecimento (US4), tendo sido assim expressa por cinco entrevistadas, três brasileiras e uma britânica. Seguem duas vinhetas.

[...]... eu tenho uma família, que eu sou consultora lá, e tem várias crianças, e a gente vê [...]... as crianças hoje elas estão, a fala, a fala diferente da minha época, fala das crianças, eles já têm assim, independência do núcleo que ele é ali educado, assim, a educação com o outro, tolerância...enfım, eu acho que a espiritualidade, ela é uma coisa que é tão individual, é de cada um, então eu vejo que um já tem um passo, outro ainda tem que dar um passo, entende? (Tamires, brasileira)

[...]... eu precisava entender o motivo de eu ter ficado doente e como melhorar, então eu pesquisei bastante coisa, incluindo a reencarnação, e eu suponho que é a conexão com suas almas, ou o que quer que seja, é uma escolha para se manifestar e aproveitar ao máximo o seu ser físico, mas se trata do seu espírito e da sua alma aprendendo e contribuindo com o que você é capaz. [...]... compreendendo sua própria natureza e quem você é. (Celine, britânica).

Ainda nesse NS, uma quinta US comporta a concepção de espiritualidade como sendo totalidade, unidade corpo e espírito como dimensões integradas, em perspectiva holística
Nicole Bacellar Zaneti, Marta Helena de Freitas e Jeremy Carrette

(NS5). Quatro entrevistadas brasileiras e uma britânica se expressam dessa forma. Vide duas vinhetas.

[...]... acho que isso tudo se chama espiritualidade, na verdade, esse conceito ele abrange uma visão de totalidade do ser humano, não é uma religião, também não é só uma filosofia, também não é só uma medicina, são vários aspectos do ser humano que tão integrados com a espiritualidade, que vem dessa descoberta de que você não é apenas material... [...]... existem várias dimensões no teu ser e você vai descobrindo essas dimensões. (Mariana, brasileira)

Eu acho que porque é tão holístico, toca todas as partes da sua vida. [...] mas eu entendo esse tipo de ação [...]... indo com a natureza, fluindo [...] eu não vejo separação, é tudo, sua fisicalidade é uma manifestação de sua espiritualidade. (Celine, britânica)

A sexta e última US, sobre a concepção de espiritualidade (US6), é expressa pela sua relação direta com a crença na vida após a morte ou em outras vidas, mesmo que ainda envolta em mistério e desconhecimento acerca dessa temática, conforme ilustram as vinhetas.

[...]...eu acredito que existe vida após a morte, ou pelo menos alguma coisa, e eu não sei o que é, ou que forma isto tomará, mas eu não [...]... Eu não acho que este seja o fim, acho que é o início de uma outra jornada. [...]... Eu não quero dizer que uma pessoa simplesmente se move para uma dimensão diferente. Eu acho que isto tem mais a ver com o espírito por completo e com a energia que se avança, mas eu não sei bem como isso se manifesta. Eu não cheguei tão longe, mas é, é assim que eu estou me sentindo no momento. (Alicia, britânica)

[...] a espiritualidade eu acho que ela vem... eu sou de uma família de cinco filhos, eu sou a caçula, e eu vejo a diferença que existe, como eu vejo, na diferença entre meus filhos, e vejo que cada um traz uma bagagem, um está mais pronto, ou menos. No sentido de tolerância, de entendimento, de paciência, então, eu tenho um filho que ele é assim, senta para conversar com ele, você fala "caramba", então, ele tem uma sensibilidade, diferente do outro. Então eu penso que, poxa, mesmo, nasceu, foi educado, e são diferentes. Então eu acho que a gente traz muito mais herança, acho que a gente traz uma bagagem, não sei te falar, se é de uma outra vida... (Tamires, brasileira)

O segundo NS, relacionado à especificidade da vivência da espiritualidade enquanto mulher (NS2), devido à riqueza e diversidade de expressões das entrevistadas, desdobrou-se em sete unidades de sentido, conforme ilustra a Figura 4.

Expressaram a vivência da espiritualidade feminina sob a 


\section{W'INTERACÃO EM ET. PSICOLOGIA}

forma de autocuidado e encontro consigo mesma (NS1) três entrevistadas, uma britânica e duas brasileiras. Aqui, foi comum referirem-se à vivência mais plena do tempo no momento em que estão meditando, conectadas consigo mesmas ou em silêncio contemplativo. Destacou-se também o autocuidado como um processo que promove maior conexão com o outro, potencializando a generosidade e o compartilhamento, sendo essas últimas mais ressaltadas na fala das brasileiras. Isso está em consonância com o que se pode apreender também na segunda US, concepção da espiritualidade feminina expressa na generosidade e encontro com o outro (US2), a qual emergiu justamente da fala de três brasileiras, nenhuma britânica. Nessas expressões, a manifestação da espiritualidade feminina foi associada à delicadeza, solidariedade, capacidade de doar, apoiar e servir aos semelhantes. Curiosamente, traços dessas mesmas características se manifestam na vivência da espiritualidade feminina por meio da experiência de maternidade ou equivalente (NS3), assim concebidas por duas brasileiras e um britânica. Nos seus relatos, em especial das brasileiras, viver a maternidade como uma experiência "divina", ou como uma espécie de "integração" com Deus, apareceu muito associado às funções femininas de gerar a criança dentro do próprio corpo, amamentar o bebê e cuidar dos próprios filhos ou de outros seres em situações equivalentes.

Por outro lado, associar a manifestação da espiritualidade a expressões religiosas tipicamente femininas - preces, louvações, ou outras atitudes próprias de beatas, freiras e santas (NS4), mostrou-se presente apenas no discurso das britânicas, em especial no de Celine, acentuando a presença da mulher nos coros e nos hinos cantados na Igreja Anglicana e também à oração de Maria; e de Bárbara, ressaltando o protagonismo das mulheres, freiras e santas, na Igreja Católica, desde a Idade Média.

Curiosamente, uma entrevistada, brasileira, associou a vivência da espiritualidade feminina em conexão com sua complementaridade pelo masculino (NS5).

Essa é profunda. Eu acho assim, eu acho que o ser masculino, o ser feminino, eles são complementares, isso aí pra mim é básico, não tem o frágil e o forte [...]... se eu tenho em mim um ser predominantemente feminino, e tenho a força do yang em mim, acho que isso tudo forma a minha espiritualidade feminina, então no Tai Chi a gente busca esse equilíbrio, não tô dizendo que seja $50 \%$ masculino e 50\% feminino, não é. (Mônica, brasileira)

Quatro entrevistadas, sendo uma brasileira e três britânicas, negaram quaisquer diferenças de gênero na vivência da espiritualidade (NS6), alegando ser essa uma experiência que se vive como pessoa, e não como homem ou como mulher. Outras duas, sendo uma brasileira e outra britânica, alegaram nunca terem pensado sobre isso (NS6).

A vivência da religião (NS3) emergiu basicamente das expressões espontâneas das entrevistadas ao relatarem suas vivências da espiritualidade e, paralelamente, as associarem ou diferenciarem de suas experiências nas instituições religiosas. Em torno desse NS, elencaram-se nove US, conforme ilustra a Figura 5. Pelas próprias expressões empregadas na nomenclatura da maioria das US, identificase a ligação delas com religiões específicas do ocidente, o

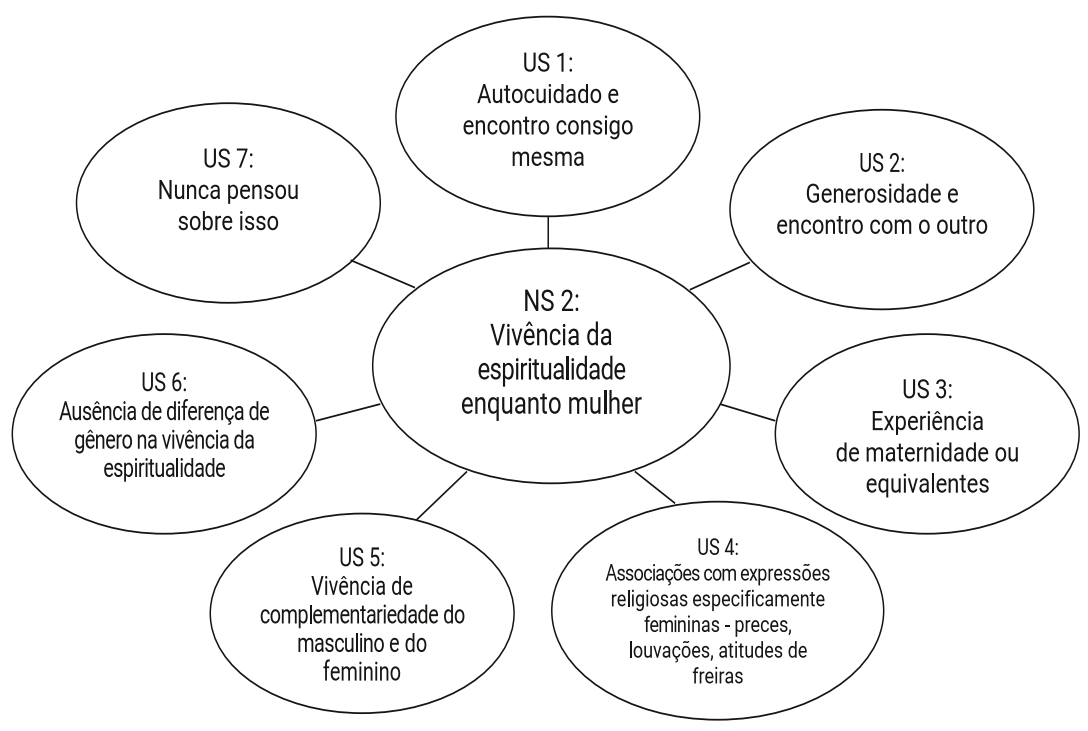

Figura 4: Vivência da espiritualidade enquanto mulher. Fonte: De "Sexualidade e espiritualidade femininas: um estudo com mulheres praticantes de Tai Chi Chuan", de N. B. Zaneti, 2017, p. 88. 
espiritismo, o catolicismo, o anglicanismo, a igreja luterana, ou oriental, como o budismo.

Apesar da crença em proposições típicas do espiritismo ter se mostrado em vários momentos nas expressões de várias entrevistas, apenas uma delas, brasileira (Vera), mencionou explicitamente sua vivência com o espiritismo (US1). Segundo ela, este the abriu novas possibilidades, inclusive a leitura de um livro de filosofia, ao final da prática de TCC, o que antes lhe pareceria impossível.

Seis entrevistadas, três brasileiras e três britânicas, relataram vivências no catolicismo (NS2). Dentre elas, a brasileira Mônica, que menciona experiência positiva no seu contato com as freiras, quando estudou em escola católica, envolvendo-se com diversas práticas sociais. Mas relata também que, quando entrou na faculdade, teve contato com algumas questões políticas dessa religião com as quais não concordou. Outras duas entrevistadas brasileiras afirmam praticar o budismo (US3). Marina relata seguir a linha vajrayana, buscando iluminação, mas sem precisar deixar de viver a vida cotidiana, procurando estar sempre consciente e presente no aqui-agora. Uma entrevistada brasileira, Aparecida, relata ser estudante da Loja Rosa Cruz (US4), e alega que a meditação que realiza nessa religião se complementa à meditação em movimento praticada no TCC.

Duas entrevistadas britânicas, Alicia e Celine, afırmam frequentar, ainda que não assiduamente, a Igreja Anglicana (US5). Alicia diz que afirmaria ser cristã, mas que, apesar de acreditar no cristianismo, não sabe se pode se considerar uma "boa cristã". Celine, filha de pastor anglicano, ainda que não pertença a nenhuma organização religiosa formal, eventualmente frequenta a igreja para ser solidária a seus pais e por gostar muito dos hinos. Apenas uma das entrevistadas, Fernanda, brasileira, afirma-se luterana (NS6) por nascimento: seu pai e seu avô eram pastores. Mas, atualmente, prefere não se rotular, afirmando que seu templo é o mundo e que a espiritualidade é vivida de forma única por cada pessoa. Duas outras entrevistadas, a brasileira Vera e a britânica Rachel, afırmam-se adeptas de experiências alternativas de misticismo, como Reiki, tarô, ciganos, curandeiros (NS7). Vera caracteriza sua busca espiritual como de cunho existencialista, realizando-se nos seus interesses por oráculos, tarô e estudos dos arquétipos. Rachel, que nasceu na Irlanda, relata o quanto assimilou dessa cultura: mesmo sendo católicos, os irlandeses sempre recorriam a curandeiros quando estavam doentes, e sua mãe via seu futuro com uma cigana.

Ainda como sentido elencado em torno da vivência da própria religião, emergiram as expressões relacionadas especificamente à influência exercida pela prática do TCC (US8), o que se fez evidente de modo mais explícito no discurso de duas entrevistas britânicas. Alicia relata que, inicialmente, vivenciava o TCC e a sua prática cristã de forma dissociada, inclusive pelo fato de alguns cristãos considerarem o TCC uma obra do demônio. Ultimamente, entretanto, ela tem percebido que as duas práticas se complementam e tem pontos em comum, citando como exemplo cenas bíblicas envolvendo a cura por meio da imposição de mãos, o que corresponderia ao que se faz com a técnica do chi kung. Também no sentido de buscar e descobrir essa conexão e integração, Celine relaciona a vivência em comunidade, na Igreja Anglicana que seu pai e sua madrasta frequentam, ao Dia Mundial do TCC, em que várias pessoas ao redor do mundo praticam a mesma sequência de movimentos do TCC no mesmo horário.

Embora tenham sido comuns, ao longo de praticamente todas as entrevistas, a tendência a se diferenciar ou a se relacionar religião e espiritualidade, apenas uma entrevistada, britânica, Sasha, posicionou-se de modo mais radicalmente crítico em relação às religiões em geral: afirmou nunca ter sentido necessidade de pertencer a uma religião (US9), de modo que até mesmo a celebração de nascimento dos filhos foi absolutamente laica. Disse considerar a fé uma mera questão geográfica.

O quarto e último NS girou em torno da influência do TCC na vivência da espiritualidade (NS4), e dele se desdobraram 12 US, conforme ilustra a Figura 6.

$\mathrm{Na}$ expressão de uma entrevistada brasileira, o TCC exerce o papel de um verdadeiro "alimento" para sua espiritualidade, nutrindo-lhe a própria "respiração" existencial (NS1). Em continuidade, a mesma participante fala de como essa prática tem lhe promovido equilíbrio, serenidade e delicadeza (NS2), características que associa à sua espiritualidade:

... eu fazia o Tai Chi dentro de um propósito de equilíbrio, de harmonia, da minha serenidade, eu sempre fui uma pessoa explosiva, e eu precisava buscar minha delicadeza, minha serenidade [...] e aí eu acho que o Tai Chi [...]... me abriu a outras relações que me propiciaram também a questão espiritual. (Vera, brasileira)

Seis participantes, sendo três brasileiras e três britânicas, apontam como influência da prática do TCC a experiência mais integrada e holística da própria espiritualidade (NS3), seja por meio da maior conexão consigo mesma, seja com o próprio universo, conforme ilustra a vinheta.

Parte do meu treinamento vai ao mínimo de respirações por hora, onde mantemos a posição. E, no início, isso era um verdadeiro desafio. Mas, uma vez que aprendi a me conectar desse jeito, isso está levando ao êxtase espiritual, uma vez que eu praticamente aprendi a relaxar 


\section{H NTERAC̄öEM ET PSICOLOGIA}

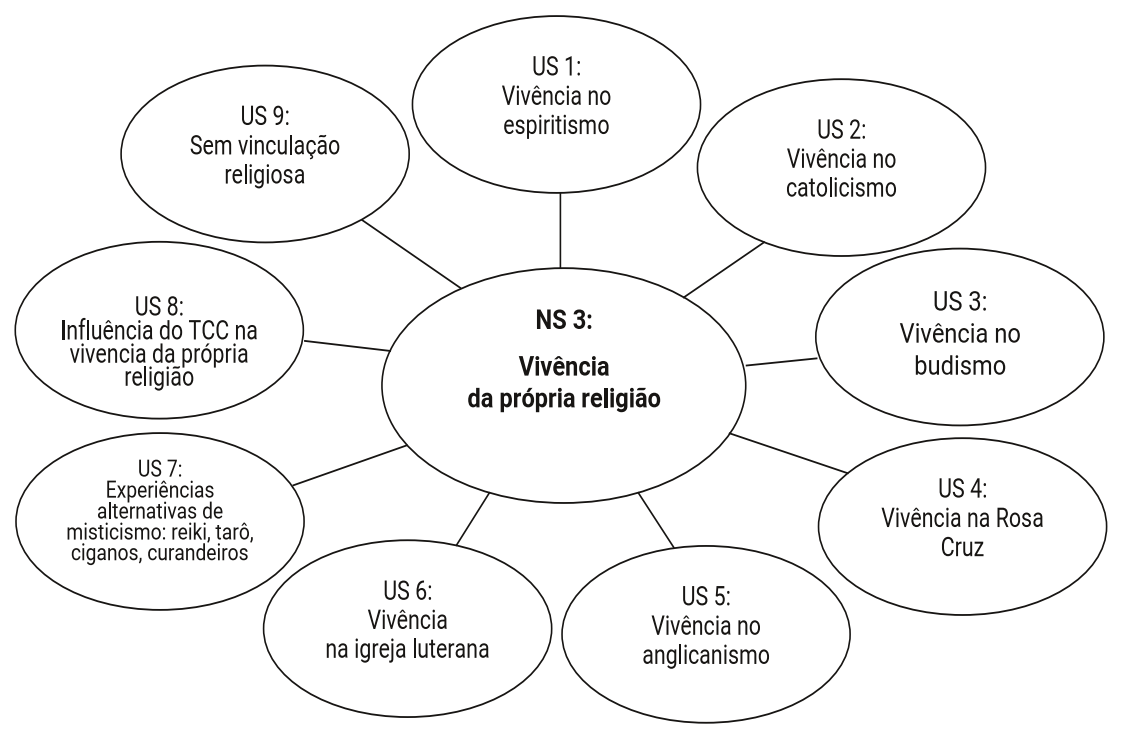

Figura 5: Vivência da própria religião. Fonte: De "Sexualidade e espiritualidade femininas: um estudo com mulheres praticantes de Tai Chi Chuan", de N. B. Zaneti,
2017, p. 94 .

com isso, então foi quando eu comecei a, comecei a sentir essa conexão rica com o universo. Mas acho que isso faz parte da espiritualidade, então, sabe? (Linda, britânica)

Duas brasileiras expressaram a influência indireta do TCC sobre sua espiritualidade (NS4), seja por abrir outras relações que acabaram trazendo, como decorrência, a expansão espiritual, como relatado por Vera, ou por levar à aproximação do budismo, que lhe trouxe a integração e completude espiritual, no caso de Marina. Por outro lado, houve também quem se mostrasse em dúvida (NS5), hesitando sobre o papel do TCC na própria espiritualidade, e.g., o caso da britânica Alicia, que sempre se considerou uma pessoa espiritualizada. Houve ainda quem alegasse, como a brasileira Vera, que o desenvolvimento da espiritualidade ocorreu de forma simultânea à prática do TCC (HS6), em decorrência de buscas paralelas e não propriamente a partir dessa prática específica.

Duas participantes, uma brasileira (Aparecida) e outra britânica (Bárbara), apontam explicitamente, como influência do TCC na vivência de sua espiritualidade, a aproximação do Taoísmo (NS7), por meio do qual desenvolveram maior capacidade de interiorização e valorização da simplicidade. A britânica Barbara ainda complementa, reafirmando que o próprio desenvolvimento da experiência espiritual genuína (NS8) é atribuída ao TCC: "Bem, certamente, na verdade, eu não tive uma experiência de espiritualidade antes de começar o tai chi. Eu estava tão desligada, pelas várias experiências que falei anteriormente..."
Finalmente, outra modalidade de influência, expressa por três participantes, uma brasileira e duas britânicas, refere-se ao desenvolvimento da sensibilidade ao contato com o próprio espírito ou o de outrem (US9). A brasileira Fernanda relata o quanto a prática a faz sentir-se mais em contato consigo mesma e com Deus. A britânica Celine alega que, ao praticar o TCC, passou a entrar em contato com gerações anteriores que o praticaram também. E a britânica Linda relata que passou a sentir a presença de outros espíritos, especialmente durante as aulas de TCC.

\section{DISCUSSÃO}

A escuta propiciada às mulheres entrevistadas nesta pesquisa, acompanhada de perguntas que as levaram a refletir sobre a vivência do TCC e da espiritualidade, mostrouse fundamental para que pudessem se expressar em profundidade, permitindo compreender, do ponto de vista qualitativo, muitos dos resultados obtidos em pesquisas quantitativas sobre o assunto. Em especial por aquelas que têm apontado efeitos positivos do TCC sobre a saúde física e mental da mulher na menopausa ou idosa, como as de Montanelli (2018); Guimarães, Lima e Cardoso (2017); Chao et al. (2013); Chyu et al. (2010); Silva (2012), dentre outras. Viu-se que todas as entrevistadas, tanto brasileiras como britânicas, buscaram o TCC visando encontrar maior qualidade de vida, seja pela superação ou prevenção de problemas de ordem física ou emocional, seja pelo desejo de uma ocupação, equilíbrio ou busca de sentido existencial. Os depoimentos mostram que os benefícios encontrados foram 


\section{W' INTERACÃO EM ET PSICOLOGIA}

percebidos como sendo tão significativos que, ao longo do tempo, elas desenvolveram verdadeira paixão pela prática, a ponto de se tornarem professoras de TCC. De um lado, o fato de serem todas professoras de TCC cria um viés na pesquisa, cujos resultados não podem ser generalizados para todas as mulheres que o praticam. De outro lado, isso ajuda a compreender um percurso de envolvimento com a prática que foi se consolidando ao longo do tempo e adquirindo sentidos que caracterizam uma verdadeira teodiceia, na qual corporeidade e espiritualidade tendem a ser vividos de modo bastante integrado, como se viu em inúmeras de suas expressões espontâneas.

Ressalte-se o quanto as entrevistadas enfatizam as vivências diretamente ligadas à corporeidade, e.g., benefícios físicos, atividade física, movimentação da energia interna, unidade corpo-espírito, autocuidado, alimento, equilíbrio, respiração, movimento, postura, sensibilidade, dentre outras, e a multiplicidade de sentidos que daí se desdobram. Uma leitura fenomenológica desse processo permite compreender a potencialidade terapêutica dessa multiplicidade de sentidos desdobrando-se de uma experiência corporal, pré-predicativa, em experiências reflexivas, intersubjetivas, espirituais e transcendentais. É como se uma espécie de feixe de sentidos passasse a ser expresso a partir da corporeidade, mas ao mesmo tempo, de modo a transcendê-la, ilustrando aquela espécie de fio ontológico descrito por Merleau-Ponty (1999/1945; 1973/1951), atando a diversidade da experiência numa mesma unidade interpretativa. Pode-se dizer, então, que os efeitos fisiológicos do Tai Chi Chuan flexibilidade, postura, equilíbrio, relaxamento, fortalecimento, dentre outros -, são portadores de uma espécie de "gênese de sentido" para as mulheres que o praticam, possibilitandoIhes, simultaneamente, reabilitar o sensível, via uma espécie de sabedoria difusa desse corpo, e a sua condição teleológica, pois é pleno de intencionalidade, significação e propulsão à transcendência.

Outrossim, pode se dizer ainda que os resultados alcançados nesta pesquisa estão em consonância com a tese de Campbel (1997), pois tanto a busca pelo TCC quanto a sua consolidação existencial na vida das entrevistadas para quem ele se tornou o "alimento" e a "própria vida" podem ser compreendidos como sintomas de um certo relaxamento da ocidentalização e de seus valores e práticas tradicionalmente pautados numa visão muito mais dicotômica entre corpo e espírito, ciência e religião, fé e conhecimento, bem e mal. Essa tendência ao relaxamento se mostra também nas diversas afirmações comparativas entre espiritualidade e religião, as quais evidenciam que as

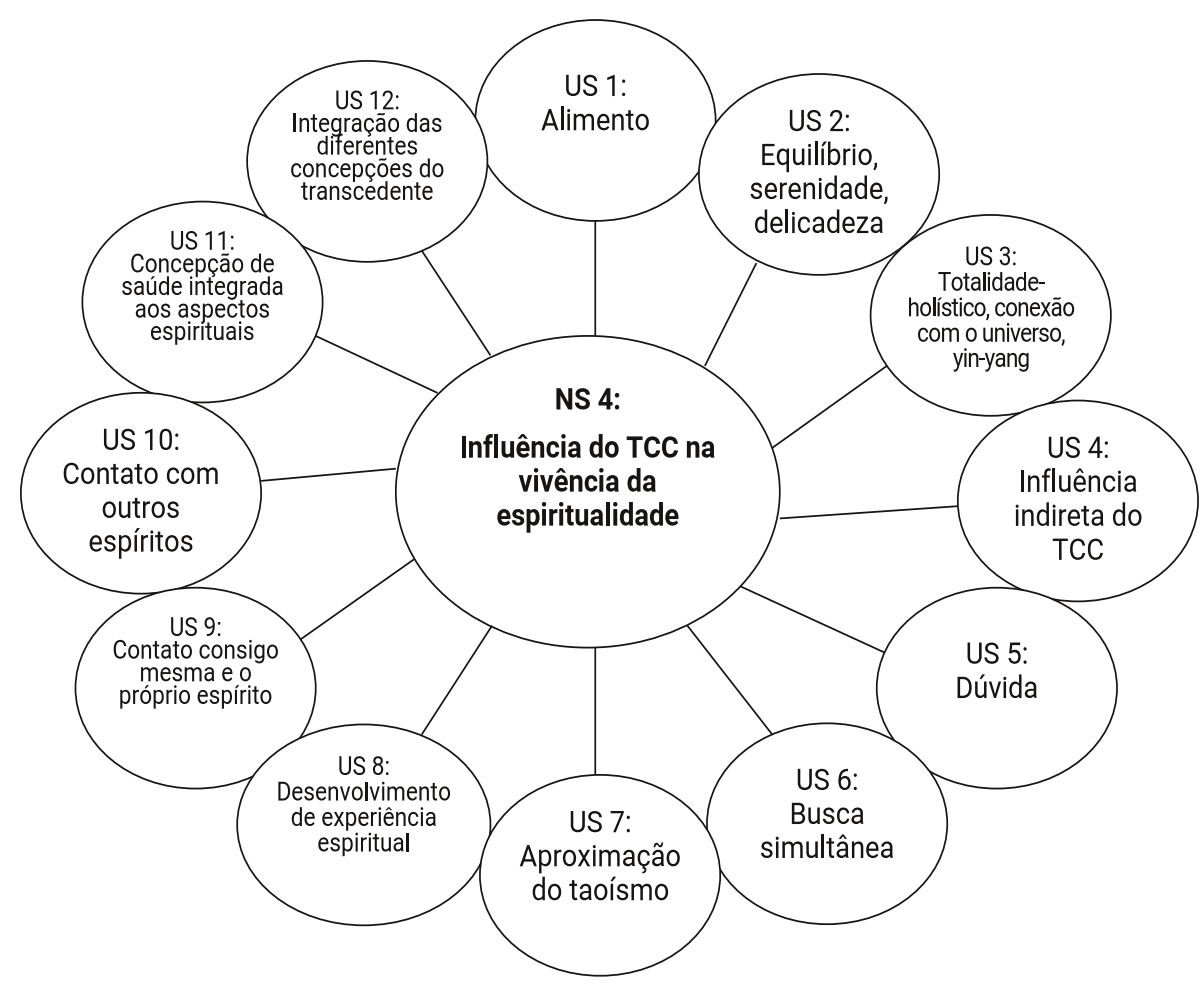

Figura 6. Influência do TCC na vivência da espiritualidade. Fonte: De "Sexualidade e espiritualidade femininas: um estudo com mulheres praticantes de Tai Chi Chuan", de N. B. Zaneti, 2017, p. 102. 


\section{MI* INTERACÃO EM LF PSICOLOGIA}

mulheres praticantes de TCC, a despeito de não terem abandonado integralmente os princípios de uma teodiceia ocidental - muitas empregam o termo Deus, em especial as brasileiras, e a maioria ainda mantém alguma ligação com as religiões cristãs, mesmo que não do mesmo modo que seus pais e avós -, agora tendem a relativizá-los ou ressignificálos, numa espécie de releitura permeada por novos paradigmas. Assim, por exemplo, viu-se que, nas formas com que as entrevistadas descreveram a vivência da espiritualidade, sobressaíram-se muito mais os núcleos de sentido que apontam para a noção de energia, ligação, conexão com o universo, contato consigo mesma ou totalidade corpo e espírito. Ainda que tenha aparecido também, em menor extensão e intensidade, a referência a um ser superior - e que, ao mesmo tempo, poderia ser Deus ou Tao -, fica expressa uma tendência muito mais significativa e frequente em experimentar a espiritualidade segundo um paradigma de conexão e horizontalidade do que vinculada a um padrão hierárquico, verticalizado, que caracterizaria uma teodiceia tipicamente ocidental.

Numa espécie de combinação entre a tese husserliana, que apontou a crise do ethos europeu, e a campbeliana, que mostrou a crise da teodiceia ocidental, pode-se ver a adesão apaixonada dessas mulheres ao TCC como forma de resgate simultâneo do sensível e do télos, os quais, por alguma razão, haviam perdido, envoltas que estavam nos padrões de uma racionalidade urbanizada, técnica, dessacralizada, midiática e consumista. Isso está em consonância com Husserl (2008/1936), ao denunciar o desenvolvimento tecnológico e a matematização ocidental como decorrências de um "racionalismo extraviado", tragicamente esquecido do mundo da vida (Lebenswelt) e intelectualmente surdo aos problemas humanos mais profundos. E se coaduna com a descrição de Campbel (1997), ao enumerar as condições que estariam levando os cidadãos ocidentais a se aproximarem mais de paradigmas inspirados na teodiceia oriental, dentre elas a busca de melhor qualidade de vida. Nesse sentido, buscam viver uma humanidade mais fundamentalmente "entrelaçada na teia da vida espiritual e sensitiva" (Campbel, 1997, p. 20), implicando experiência mais individualizada ("contato consigo mesma"), mas também mais propulsora de integração entre religiosidade, vivência corporal, espiritualidade e saúde física e mental ("totalidade").

Por outro lado, as experiências e concepções de corporeidade e espiritualidade compartilhadas pelas mulheres praticantes e professoras de TCC, brasileiras e inglesas, mostraram o quanto elas ainda transitam entre os dois universos / teodiceias - corpo e espírito, religião e espiritualidade, materialidade e transcendência, individualidade e conectividade, reflexividade e sensibilidade, ocidente e oriente. Nessas idas e vindas, as inflexões aparecem com muita frequência em suas narrativas. A despeito delas, o esforço de síntese entre as polaridades ("yang e ying") fica bem evidenciado quando relatam que, inicialmente, a opção pelo TCC significou um afastamento de suas religiões de origem, mas que, mais recentemente, tem vislumbrado muito mais aproximações, conexões ou complementaridades entre ambos. Isso, por sua vez, faz remeter aos versos de Goethe, que agora, ao final deste artigo, substituem as vinhetas: "Aquele que conhece a si mesmo e ao outro, também reconhecerá que o Oriente e o Ocidente não podem ser separados".

\section{DECLARAÇÃO DE FINANCIAMENTO}

A pesquisa relatada no manuscrito foi financiada parcialmente pela bolsa de doutorado da primeira autora (CAPES/PROSUP)

\section{DECLARAÇÃO DA CONTRIBUIÇÃO DOS AUTORES}

Certificamos que todos os autores participaram suficientemente do trabalho para tornar pública sua responsabilidade pelo conteúdo. A contribuição de cada autor pode ser atribuída como se segue:

N. B. Z., M. H. F. e J.C. contribuíram para a conceitualização, investigação e visualização do artigo; N.Z. e M.F. fizeram a redação inicial do artigo (rascunho) e N. B. Z. e M. H. F. são as responsáveis pela redação final (revisão e edição).

\section{DECLARAÇÃO DE CONFLITOS DE INTERESSE}

Os autores declaram que não há conflitos de interesse no manuscrito submetido.

\section{AGRADECIMENTOS}

Os autores agradecem a Arlene Almeida e Vanessa Castro pelo apoio na transcrição das entrevistas.

\section{REFERÊNCIAS}

Aletti, M. (2012). Novas formas da religião numa cultura plural, à luz da Psicologia e da psicanálise. In M. H. de Freitas \& G. J de Paiva (Orgs.), Religiosidade e cultura contemporânea: desafios para a psicologia (pp. 99-139). Brasília, DF: Universa. 


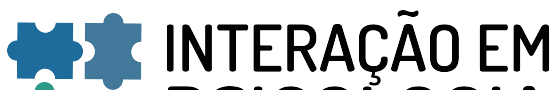 ET PSICOLOGIA}

Amatuzzi, M. M. (2001). Pesquisa fenomenológica em psicologia. In M. A. T. Bruns \& A. F. Holanda (Orgs.) Psicologia e pesquisa fenomenológica: Reflexões e perspectivas (pp. 15-22). São Paulo, SP: Ômega.

Brasil. Ministério da Saúde. Secretaria de Atenção à Saúde. Departamento de Atenção Básica. (2006). Política Nacional de Práticas Integrativas e Complementares no SUS - PNPIC-SUS. Disponível em: http:// bvsms.saude.gov.br/bvs/publicacoes/pnpic.pdf

Campbel, C. (1997). A orientalização do Ocidente: reflexões sobre uma nova teodicéia para um novo milênio. Religião \& Sociedade, 18(1), 5-22.

Carrette, J. (2007). Religion and critical psychology: religious experience in the knowledge economy. Journal of Management, Spirituality \& Religion, 8(4), 279-280.

Carrette, J. \& King, R. (2005). Selling spirituality: The silent takeover of religion. Londres e Nova Iorque: Taylor \& Francis e-Library.

Chang, J. (1979). O taoísmo do amor e do sexo: O êxtase e a milenar sabedoria do amor (J. E. Moretzohn, Trad.). Rio de Janeiro: Artenova.

Chao, C. H. N., Costa, E. C., Elsangedy, H. M., Savir, P. A. H., Alves, E. A. \& Okano, A. H. (2012). Efeito da prática do Tai Chi Chuan sobre a resistência aeróbica de idosas sedentárias. Revista Brasileira de Geriatria e Gerontologia, 15(4), 627-633. doi: 10.1590/S180998232012000400003.

Chyu, M. C., James, C. R., Sawyer, S. F., Brismée, J. M., Xu, K. T., Poklikuha, G., ..., último autor (2010). Effects of tai chi exercise on posturography, gait, physical function and quality of life in postmenopausal women with osteopaenia: a randomized clinical study. Clinical Rehabilitation, 24, 1090-1090. doi: $10.1177 / 0269215510375902$.

Despeux, C. (1981). Tai Chi Chuan: Arte marcial, técnica da longa vida. (O. M. Cajado, Trad.). São Paulo: Pensamento.

Freitas, M. H. (2016). Psicologia religiosa, psicologia da religião / espiritualidade, ou psicologia da religião / espiritualidade? Pistis \& Praxis, 9(1), 89-107. doi: 10.7213/2175-1838.09.001.DS04

Freitas, M. H. (2017). Psicologia religiosa, psicologia da religião / espiritualidade, ou psicologia da religião / espiritualidade? In M. R. G. Esperandio \& M. H. Freitas (Orgs.), Psicologia da Religião no Brasil (pp. 61-76). Curitiba, PR: Juruá.

Freitas. M. H. (2019). Religiosity, Spirituality and Wellbeing in the perception of Brazilian health and mental health professionals. In B. Schmidt \& J. Leonardi, Spirituality and Wellbeing. Sheffield, UK: Equinox. (No prelo).
Nicole Bacellar Zaneti, Marta Helena de Freitas e Jeremy Carrette

Freitas, M. H. \& Vilela, P. R. (2017). Leitura fenomenológica da religiosidade: Implicações para o psicodiagnóstico e para a práxis clínica psicológica. Revista da Abordagem Gestaltáltica, 23(1), 95-107. Disponível em: http:// pepsic.bvsalud.org/scielo.php? script=sci_arttext\&pid=S1809-68672017000100011

Giorgi, A. (2009). The descriptive phenomenological method in psychology: A modified Husserlian approach. Pittsburg: Duquesne University Press.

Giorgi, A. (2012). The descriptive phenomenological psychological method. Journal of Phenomenological Psychology, 43(1), 3-12. doi:10.1163/156916212X632934

Gomes, W. (1997). A entrevista fenomenológica e o estudo da experiência consciente. Psicologia USP, 8(2). doi:10.1590/ S0103-65641997000200015

Guimarães, J. S., Lima, A. P. \& Cardoso, F. B. (2017). Efeito da prática do Tai Chi Chuan na autoestima e autoimagem de idosos. Revista Brasileira de Prescrição e Fisiologia do Exercício, 11(71), 952-959. Disponível em: http:// www.rbpfex.com.br/index.php/rbpfex/article/view/ $1317 / 1005$

Husserl, E. (2008). A crise da humanidade europeia e a Filosofia (P. M. S. Alves, Trad.). Covilhã: LusoSofia (Obra original publicada em 1936).

Koenig, H. G. (2006). Medicine, Religion, and Health: Where Science and Spirituality Meet (pp. 9-20). West Conshohocken, Pennsylvania: Templeton Foundation Press.

Lindquist, R., Tracy, M. F. \& Snyder, M. (2018). Complementary \& alternative therapies in nursing. New York: Springer.

Mateu, F. P. (2015). Tai Chi Chuan y la salud: Estudio médicoeducativo. Lliurament final del Pràcticum i presentació virtual. Estudios de Asia Oriental, Universitat Oberta de Catalunya. Disponível em: http://openaccess.uoc.edu/ webapps/o2/bitstream/10609/44621/6/fplanasma Practicum0615memoria.pdf

Merleau-Ponty, M. (1999). Fenomenologia da percepção (C. A. R. Moura, Trad.). São Paulo: Martins Fontes. (Obra original publicada em 1945).

Merleau-Ponty, M. (1973). Ciências do Homem e Fenomenologia. São Paulo: Saraiva. (Obra original publicada em 1951)

Montanelli, D. E. G. (2018). Tai Chi Chuan y Calidad de Vida en Adultos Mayores. Buenos Aires: Fundación Columbia de Conciencia y Energía. Disponível em: https:// www.fundacioncolumbia.org/template/pdf/ tai_chi_adultos_mayores.pdf 


\section{-4: INTERACÃO EM IT PSICOLOGIA}

Moreira-Almeida, A., Pinsky, I., Zaleski, M. \& Laranjeira, R. (2010). Envolvimento religioso e fatores sociodemográficos: resultados de um levantamento nacional no Brasil. Revista de Psiquiatria Clínica, 37(1), 12-5. doi:10.1590/S0101-60832010000100003

Nascimento, M. C., Barros, N. F., Nogueira, M. I. \& Luz, M. T. (2013). A categoria racionalidade médica e uma nova epistemologia em saúde. Ciência \& Saúde Coletiva, 18(12), 3.595-3.604. doi:10.1590/S1413-81232013001200016

Nogueira, M. I. \& Carmargo Jr., K. R. (2007). A orientalização do Ocidente como superfície de emergência de novos paradigmas em saúde. História Ciências Saúde Manguinhos, 14(3), 841-861. doi:10.1590/S010459702007000300009

Paiva, G. J. (2004). Espiritualidade e qualidade de vida: pesquisas em psicologia. In E. F. B. Teixeira, M. C. Müller \& J. D. T. Silva (Orgs), Espiritualidade e Qualidade de Vida (pp. 119-130). Porto Alegre: EDIPUCRS.

Saizar, M. M., Sarudiansky, M. \& Korman, P. K. (2013). Salud mental y nuevas complementariedades terapéuticas. La experiencia en dos hospitales públicos de Buenos Aires, Argentina. Psicologia \& Sociedade, 25(2), 451-460. Disponível em: http://www.scielo.br/pdf/psoc/ v25n2/22.pdf
Nicole Bacellar Zaneti, Marta Helena de Freitas e Jeremy Carrette

Silva, N. A. (2010). Efeitos do Tai Chi Chuan sobre o equilíbrio corporal em idosas com baixa massa óssea. Dissertação de Mestrado, Universidade de Brasília, Brasília, DF.

Tesser, C. D. (2009). Práticas complementares, racionalidades médicas e promoção da saúde: contribuições pouco exploradas. Cadernos de Saúde Pública, 25(8), 1732-1742. doi:10.1590/S0102311X2009000800009

Tesser, C. D. \& Barros, N. F. (2008). Medicalização social e medicina alternativa e complementar: pluralização terapêutica do Sistema Único de Saúde. Revista de Saúde Pública, 42(5), 914-20. doi:10.1590/S003489102008000500018

Zaneti, N. B. (2017). Sexualidade e espiritualidade femininas: um estudo com mulheres praticantes de Tai Chi Chuan. Tese de doutorado, Universidade Católica de Brasília, Brasília, DF.

Wile, D. (2008). Taijiquan y Taoísmo. Revista de Artes Marciales Asiáticas, 3(1), 8-45. doi:10.18002/ rama.v3i1.345

Recebido em 13.03.2019 Primeira Decisão Editorial em 18.04.2019 Aceito em 21.05.2019 